\title{
Changes in incidence and age distribution of scabies: retrospective cohort study in a tertiary hospital
}

\section{Uyuz insidansı ve yaş dağılımındaki değişiklikler: Bir üçüncü basamak hastanede retrospektif bir kohort çalışması}

\section{Habibullah Aktaș ${ }^{1}$, Aybala Cebecik ${ }^{2}$}

\begin{abstract}
Aim: Scabies is a pruritic skin disease caused by an ectoparasite named sarcoptes scabies var hominis. It sometimes makes endemics depending on lifestyles of communities. In this study, we point out that patient with scabies have increased in recent years.

Methods: A retrospective review was carried out in the patients with scabies diagnosis between 2013January and 2018 July at the dermatology outpatient clinic of Karabuk Research and Training Hospital. The age and gender of the patients, and the season of diagnosis were recorded from the hospital database.

Results: In this study, we found that the incidence of scabies increased from $0.4 \%$ to $1 \%$ in the last 5 years in the dermatology outpatient clinic of our hospital $(\mathrm{r}=0,886 \mathrm{p}=0.000)$. The mean age of scabies patients decreased from 49.7 to 31.4 within 5 years $(\mathrm{r}=-0,753 \mathrm{p}=0,006)$. The female patients were much more than male patient ( $56 \%$ vs $44 \%$ ), and their mean age was older than males (44 vs 37) ( $\mathrm{p}=0,000)$.

Conclusion: Scabies cases are increasing in number and the mean age of the patients is decreasing gradually at recent years.
\end{abstract}

Keywords: Gender, scabies, young population

Öz

Amaç:Uyuz, sarkoptes scabies var hominis adlı bir ektoparazitin neden olduğu kaşıntılı bir deri hastalığıdır.Değişen hayat tarzlarına bağlı olarak endemiler yapmaktadır.Bu çalışmada uyuz tanısı alan hastaların son yıllarda arttığına dikkat çektik.

Yöntemler: Karabük Eğitim ve Araştırma Hastanesi Dermatoloji polikliniğinde 2013 Ocak -2018 Temmuz arasında, uyuz tanısı alan hastalar retrospektif olarak incelendi.Hastane kayıtları kullanılarak yapılan çalışmada,uyuz tanılı hastaların yaş ve cinsiyetleri alındı.Uyuz tanısının konulduğu mevsim not edildi.

Bulgular:Çalışmamızda, son beş yıl içinde , hastanemiz dermatoloji polikliniğinde uyuz görülme sıklığının \% 0.4 den \%1'e kadar yükseldiğini saptadık $(\mathrm{r}=0,886 \mathrm{p}=0,000)$. Uyuz tanısı alan hastaların yaş ortalamasının da, bu 5 yıl içinde 49.7'den 31.4 'e düştüğünü gözledik $(\mathrm{r}=-0,753 \mathrm{p}=0,006)$. Uyuz tanılı kadın hastalar daha fazlaydı (\%56 vs \%44) ve uyuzlu kadın hastaların yaş ortalaması erkek hastaların yaş ortalamasına göre daha büyüktü (44 'e 37) $(\mathrm{p}=0,000)$.

Sonuç: Son yıllarda,uyuz tanısı konulan olgular artıyor ve uyuz görülme yaşı da düşüyor.

Anahtar kelimeler: Cinsiyet,genç nüfus,uyuz
1 Karabuk University Faculty of Medicine, Department of Dermatology, Karabük, Turkey. 2 Karabuk University Faculty of Medicine, Department of Family Medicine, Karabük, Turkey.

Ethics Committee Approval: The study wass approved by the local ethical authority.

Etik Kurul Onayı: Çalışma lokal etik komite tarafindan onaylanmıştır.

Conflict of Interest: No conflict of interest was declared by the authors.

Çıkar Çatışması: Yazarlar çıkar çatışması bildirmemişlerdir.

Financial Disclosure: The authors declared that this study has received no financial support.

Finansal Destek: Yazarlar bu çalışma için finansal destek almadıklarını beyan etmişlerdir.

Gelis Tarihi / Received: 17.08.2018

Kabul Tarihi / Accepted: 06.12.2018 Yayın Tarihi / Published: 15.03.2019

Sorumlu yazar / Corresponding author: Habibullah Aktas

Adres/Address: Karabuk Training and Research Hospital Department of Dermatology

Karabuk/Turkey

e-posta: aktashabib@hotmail.com

Tel/Phone: 05324084611

Copyright $(\subset$ ACEM 


\section{Introduction}

Scabies is an itchy skin disease caused by an ectoparasite, sarcoptes scabies var hominis. It has been known for 2500 years and affects 300 million people a year worldwide. It is more common in people with low income. This parasite has a life cycle of human compulsory; it can live up to only 2-3 days outside of human skin. The most prominent clinical manifestation of scabies is severe itching, especially localized in abdominal circumference, hand and foot ankles and genital area. Face and interscapular area are not involved, but may be widespread involvement in immunosuppressant or elderly patients including those areas as well. Although the history and clinical appearance often predispose to the diagnosis of the disease, direct microscopy, dermatoscopy, reflexive confocal microscopy and even biopsy help in difficult cases [1-3].

Scabies is a disease, especially of developing countries. Chronic renal and rheumatic heart diseases which can be seen as a complication of streptococcal skin infections that develop secondary to infections in young patients are remarkable social health problems [4].

Scabies has been reported more frequently in the pediatric age group, and in terms of sex, some studies have found male patients to be more frequent in contrast to some others [5, 6]. Female patients were found more frequently in studies conducted in our country [7].

We hypothesised that there is an increase in scabies cases in our city at recent years. Therefore, we aimed to evaluate incidence and demographic data of of scabies in recent years.

\section{Material and methods}

The study included patients diagnosed as scabies at the dermatology outpatient department in Karabuk Training and Research Hospital between January 2013 and July 2018. Ethical approval of was taken from Karabuk University local ethics committee (6-19/18.6.2018). Written consent could not be taken due to the retrospective design of the study. The study was performed in accordance with Declaration of Helsinki.

Data containing age and sex of the patients, and the season that scabies diagnosis was put were obtained from the hospital records. Scabies was diagnosed clinically by a dermatologist. Patients with scabies recorded in other departments such as pediatrics were not included in this study.

Since all patients diagnosed with scabies in the dermatology database were evaluated, no exclusion criteria were defined.

Patients with scabies were evaluated according to the years and the seasons. They were also categorized based on age and sex, and analysed for patients whose age was $>40$ years.

\section{Statistical analysis}

All statistics were performed using SPSS version 20.0 for Windows. Normally distributed continuous and categorical variables were expressed as mean \pm standard deviation and frequencies and percentages, respectively. Student's $\mathrm{t}$ - test, ANOVA and Spearman's rank correlation coefficient were used as statistical methods to interprete outcomes. The statistical results were presented with a $95 \%$ confidence interval. The differences were accepted statistically significant in case of $\mathrm{p}$ value $<0.05$.

\section{Results}

Within the specified period (2013 January - 2018 July), 1947 patients were diagnosed as scabies. They were 1090 women (56\%) and 857 men (44\%). The mean age of the patients was 41,1 years. The mean age of male patients was $37 \pm 22.43$ years, while the mean age of female patients was $44.5 \pm 21.97$ years $(p=0.001)$. The details of total number of the patients and their mean ages according to the years are shown at Table 1.

Table 1: Number of patients with scabies according to years

\begin{tabular}{ccccc} 
Year & $\begin{array}{c}\text { Total } \\
\text { number and } \\
\text { age } \\
\text { of cases }\end{array}$ & $\begin{array}{c}\text { Scabies } \\
\text { per } \\
1000 \\
\text { cases }^{\beta}\end{array}$ & $\begin{array}{c}\text { Total } \\
\text { number and } \\
\text { age of male } \\
\text { patients }^{\S}\end{array}$ & $\begin{array}{c}\text { Total number } \\
\text { and age of } \\
\text { female } \\
\text { patients }^{\S}\end{array}$ \\
\hline 2013 & $165(49.7)$ & 4 & $73(46.3)$ & $92(52.2)$ \\
2014 & $262(48.7)$ & 5 & $97(46.3)$ & $165(50.2)$ \\
2015 & $341(46.4)$ & 5 & $152(40.8)$ & $189(51.5)$ \\
2016 & $364(41.7)$ & 6 & $155(38.7)$ & $209(43.8)$ \\
2017 & $439(37.3)$ & 7 & $216(31.8)$ & $223(42.6)$ \\
2018 & $377(31.4)$ & 10 & $165(29.2)$ & $212(33.2)$ \\
\hline Total & $1947(41.1)$ & & $857(37)$ & $1090(44)$
\end{tabular}

§. number (mean age)

: number of scabies patients per 1000 dermatological patients

¥: the first 6.5 months.

Figure 1 shows the distribution of the cases throughout the years. There was a clear and significant increase in the number of the cases starting from $0.4 \%$ in 2013 to $1 \%$ in 2018 $(\mathrm{r}=0.886, \mathrm{p}=0.001)$. Number of the patients with scabies was much higher in both 2017 and 2018 compared to 2013 ( $\mathrm{r}=0.886$, $\mathrm{p}=0.001)$ (Table 1).

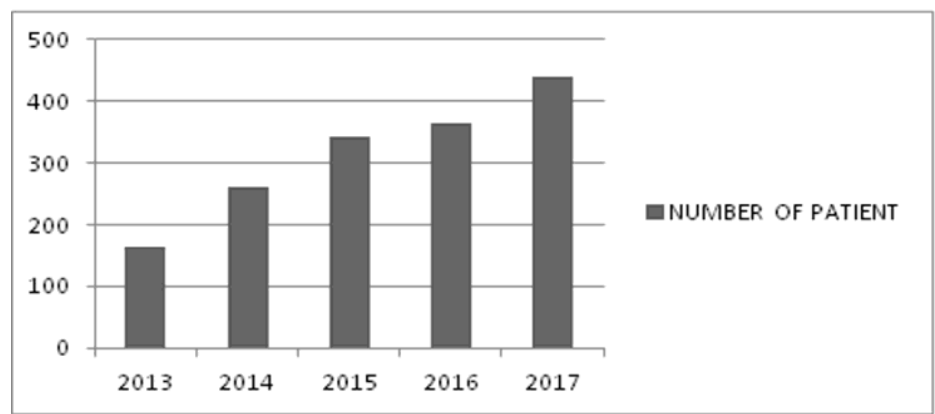

Figure 1. Number of patients with scabies according to the years.

The mean age of the patients with scabies was also found to decrease in both males and females from 49.7 years in 2013 to 31.4 years in $2018(\mathrm{r}=-0.753, \mathrm{p}=0.006)$ (Figure 2).

Figure 3 points the number of scabies cases seen at different seasons throughout the years. Winter was the most common season in which scabies was seen $(\mathrm{p}=0.001)$.

Proportion of female patients over 40 years of age was higher than males $(\mathrm{p}=0.005)$ (Table 2).

Table 2. Proportion of the patients over 40 years old according to sex.

\begin{tabular}{lccc} 
Year & $\begin{array}{c}\% \text { of all } \\
\text { patients }\end{array}$ & $\begin{array}{c}\% \text { of male } \\
\text { patients }\end{array}$ & $\begin{array}{c}\% \text { of female } \\
\text { patients }\end{array}$ \\
\hline 2013 & 68.4 & 63.0 & 72.8 \\
2014 & 66.0 & 53.6 & 73.3 \\
2015 & 58.6 & 44.7 & 69.8 \\
2016 & 50.2 & 41.9 & 56.4 \\
2017 & 41.2 & 28.2 & 53.8 \\
$2018^{¥}$ & 32.0 & 24.2 & 38.2 \\
\hline Total & 49.8 & 38.7 & 58.6 \\
\hline
\end{tabular}

$¥$ : The first 6.5 months. 


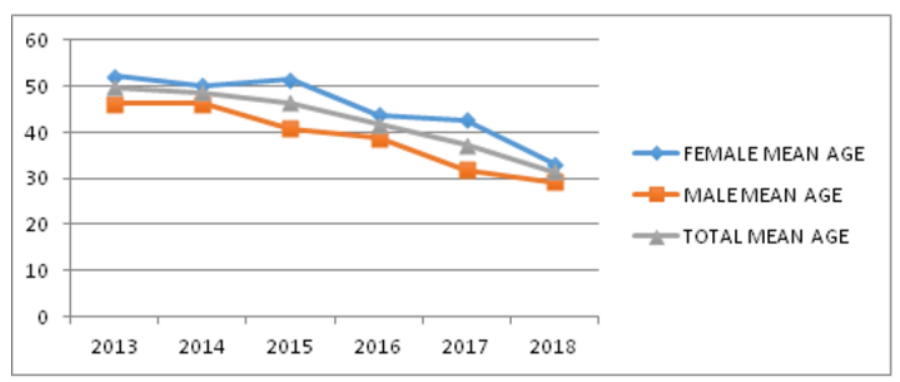

Figure 2. Mean age of all patients categorized according to sex.

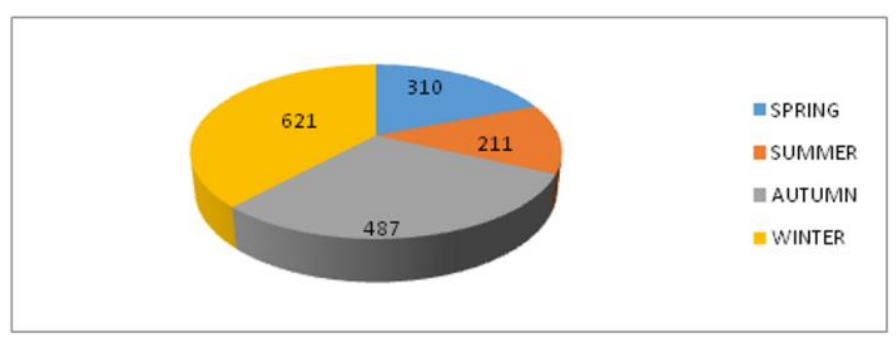

Figure 3. Number of scabies cases according to season.

\section{Discussion}

Scabies continues to be a social health problem despite urbanization and effective hygienic methods. It seems to be increased at recent years due to crowded lifestyles in developing countries just like we detected in this study. Scabies is a condition that should not be neglected in children, especially since it affects frequency of septic bacterial infections and indirectly incidence of glomerulonephritis and rheumatic heart diseases, as well as impairment of life comfort caused by intense pruritus $[4,8,9]$.Control of scabies endemics can also reduce incidence of glomerulonephritis and rheumatic heart disease in the community. Fortunately, we did not see any patient presenting with these findings or being exposed to these complications during the follow-up.

Scabies is known to be a problem of developing countries. It is most commonly seen in the tropical geography of the world. Its frequency varies from 2.7 cases per 1000 to $46 \%$ among the dermatology patients in the literature. This high rate might be attributed to an endemic outbreak [10]. Our study found that the diagnosis of scabies increased from 4 to 10 for 1000 dermatology patients between 2013 and 2018.

Although scabies is thought to be a problem of hot climates [11], our results shows that scabies is seen more frequently in the cold seasons in our geography. In the present study, scabies was identified mostly in winter season, then, autumn, spring and summer seasons respectively, as confirmed in some other studies [12-14].

In a study conducted between 1994 and 1996, Karaoğlu et al. [14] found the rate of scabies to be $3.25 \%$, equally observed in both sexes, and most frequently in childhood. These findings do not coincide with our results. We observed scabies mostly in middle-aged people and women.

In the study of Çetinkaya et al. [7], female patients and middle age group constituted the most frequent group of patients. Our findings also show similarity as to those results. In our study, the most frequent age group of scabies is the middle and advanced age group, but there was a significant increase in the number of young patients over the years. So, the mean age of patients with scabies has decreased. Probably, the reason for this was the crowded lifestyle of university students which increase in number, and immigrants placed in the city. In the epidemiological study conducted by Tüzün and his colleagues
[15] in 1980, scabies was reported more commonly in males and in ages between 15-44 years. A finding of this study was that, as we observed, it peaked in the winter months. Predominance of female patients in our study may be the result of change in life conditions as women may be more involved in social life than in 1980 .

Karaman et al. [16] reported that scabies were more frequent in female patients as in our results. Gender distrubition of scabies varies based on study and country [17].

Pannell et al. [6] reported that the most common age group was between 15 and 24 years of age. This observation is similar to our observations of the past few years. Although it has been reported that scabies is more frequent in young people [6], this is not compatible with our findings. One reason for this is that a significant proportion of childhood scabies cases may be referred to pediatric outpatient clinics.

It is known that the incidence of scabies epidemics coincides with the increase in the use of common clothes and the culture of crowded living [18]. The fact that the scabies cases of the recent five years have been increasing and the mean age has also been falling constantly implies the marked change in the sociocultural structure of the city in which we studied.

When we look at the data given 5 years ago, $63 \%$ of male cases and $72 \%$ of male cases were over 40 years old. This would need an explanation for the reason at that time. When compared to the prevalence study conducted by Çetinkaya et al. [7] in Kayseri province, our results showed a regular increase, unlike the results of Çetinkaya et al. [7]. It is difficult to explain the difference when we think that Kayseri province is also a busy student city. It is likely that the young population of our city suddenly increased. Therefore, there may not be sufficient experience in the hygiene of common living areas such as dormitories, aparts etc.

The main limitation of our study was that the study is retrospective. The fact that the diagnoses were confirmed in response to the treatment would strengthen the data. In additon, data of pediatrics department and primary care health centers were not included. This would probably change the total number and the mean age of scabies cases .

In conclusion, our study clearly showed that scabies is much more seen as to the past years, and the number of young patients also increases.

\section{References}

1. Khalil S, Abbas O, Kibbi AG, Kurban M. Scabies in the age of increasing drug resistance. PLoS Negl Trop Dis.2017;30:11.

2. Falay T, Gurel MS.Uyuz.Turkiye Klinikleri J Dermatol-Special Topics. 2017; 10:143-53.

3. Thomas J, Peterson GM, Walton SF, Carson CF, Naunton M, Baby KE. Scabies: an ancient global disease with a need for new therapies. BMC Infect Dis.2015;15:250.

4. Hay RJ,Steer AC, Engelman D, Walton S. Scabies in the developing world--its prevalence, complications, and management. Clin Microbiol Infect. 2012;18:313-23.

5. Anderson KL, Strowd LC. Epidemiology, Diagnosis, and Treatment of Scabies in a Dermatology Office.J Am Board Fam Med. 2017;30:78-84.

6. Pannell RS, Fleming DM, Cross KW. The incidence of molluscum contagiosum, scabies and lichen planus. Epidemiol Infect. 2005;133:985-91.

7. Çetinkaya Ü, Şahin S, Ulutabanca RÖ. The Epidemiology of Scabies and Pediculosis in Kayseri. Turkiye Parazitol Derg. 2018;42:134-7.

8. Marks M, Taotao-Wini B, Satorara L, Engelman D, Nasi T,Mabey DC, et al. Long Term Control of Scabies Fifteen Years after an Intensive Treatment Programme. PLoS Negl Trop Dis. 2015;9:e0004246.

9. Thornley S, Marshall R, Jarrett P, Sundborn G, Reynolds E, Schofield G. Scabies is strongly associated with acute rheumatic fever in a cohort study of Auckland children. J Paediatr Child Health. 2018;54:625-32. 
10. Fuller LC. Epidemiology of scabies. Curr Opin Infect Dis. 2013;26:123 6.

11. Figueroa JI, Fuller LC, Abraha A, Hay RJ. Skin disease in south western Ethiopia: rationale for a community approach. Int J Dermatol.1998;37:752-8.

12. Savin JA. Scabies in Edinburgh from 1815 to 2000. J R Soc Med. 2005;98:124-9.

13. Mimouni D, Ankol OE, Davidovitch N, Gdalevich M, Zangvil E, Grotto I. Seasonality trends of scabies in a young adult population: a 20 -year follow-up. Br J Dermatol. 2003;149:157-9.

14. Karaoğlu S. Amasya'da 1994-96 Yı1ları Arasında Uyuzun Durumu. T Klin J Dermatol. 1997;7:10-12.

15. Tüzün Y, Kotoğyan A, Cenesizoğlu E, Baransü O, Ozarmağan G, Ural $A$, et al. The epidemiology of scabies in Turkey. Int J Dermatol.1980;19:41-4.

16. Karaman Ü, Enginyurt Ö, Dündar Y, Baykal MK, Gür S. Infestation of Sarcoptes Scabiei and Pediculus Capitis in Terms of Socio-Economical Status.ODU J Med. 2014;2:23-9.

17. Lapeere H, Naeyaert JM, De Weert J, De Maeseneer J, Brochez L. Incidence of scabies in Belgium. Epidemiol Infect. 2008;136:395-8.

18. Sara J, Haji Y, Gebretsadik A. Scabies Outbreak Investigation and Risk Factors in East Badewacho District, Southern Ethiopia: Unmatched Case Control Study. Dermatol Res Pract. 2018;2018:7276938. 